REVISTA CHILENA DE LITERATURA

Noviembre 2009, Número 75, 129 - 156

\title{
CONSTRUCCIÓN DE UNA POÉTICA ANTISOLAR EN MAHFUD MASSÍS ${ }^{1}$
}

\author{
María Olga Samamé B. \\ Universidad de Chile \\ msamame@uchile.cl
}

\section{RESUMEN / ABSTRACT}

Mahfud Massís, hijo de la emigración árabe en Chile y perteneciente a la Generación del 28, expone en su obra lírica su teoría de la imagen poética y, en virtud de ella, trabaja el tema de la muerte como eje que recoge el desgarro del mundo de su época, y lo despliega desde distintos ángulos: horror, angustia, dolor, cosmos, ancestro, Dios silente. La construcción de su imaginario poético peculiar trasciende a la experiencia ordinaria y la presencia de la cultura árabe y occidental, con su marca de angustia y horror, devienen claves decisivas.

PALABRAS CLAVE: imagen poética, ancestro árabe, tema de la muerte, drama interior, búsqueda de la trascendencia.

Mahfud Massis was born in Chile in a family of arab origin; he belonged to the so-called Generation of '28. This essay examines his theory of the poetical image and his work on the subject of death as an axis which allows us to understand the heart-rending experience of his time; he develops this subject from various aspects: the relation of death and horror, distress, pain, the cosmos, the silent God. The construction of his particular poetical imagery transcends ordinary experience, and the influence of both arab and western cultures, with their specific brands of distress and horror, are to be understood as clear keys to his poetry.

KEY WORDS: poetical image, arab origin, death as (poetical) subject, interior drama, search for transcendence.

1 Artículo derivado de la tesis doctoral, Muerte y deshumanización en la biografía y poética de Mahfud Massís, de la autora, dirigida por el profesor Grínor Rojo y el copatrocinio del profesor Naín Nómez. 
En las Américas y en Chile en particular, algunos escritores descendientes de árabes dedican una parte de su producción a escribir obras con cierta autonomía, reconstruyendo, por ejemplo, modelos narrativos ancestrales rescatados de la memoria, o inspirados, desde sus particulares perspectivas, en la forma neomahŷarí ${ }^{2}$. Entre ellos se destaca el escritor chileno Mahfud Massís (Iquique 1916 - Caracas 1990), hijo de padre palestino y madre libanesa. Se casó con la pintora Lukó de Rokha, hija del poeta Pablo de Rokha. Su producción literaria, publicada en Chile y en Venezuela, comprende fundamentalmente poesía y, en menor proporción, ensayo, cuento, crónica y teatro ${ }^{3}$. Este hijo de árabes perteneció, al menos cronológicamente, a la Generación de $1938^{4}$,

2 En rigor, el término mahŷar proviene del árabe haŷara-yahŷuru, emigró-emigra, saliósale; verbi gracia, al-Hiŷara o la Hégira es la salida (que realizó el profeta Muhammad desde La Meca a Yatrib -más tarde Medina- y que inició la era islámica); mahŷar es el lugar de emigración de árabes a las Américas, y también es la denominación que la literatura árabe contemporánea le otorga a la literatura creada por los intelectuales árabes emigrantes en las Américas y cuyas obras conllevan la triple impronta de la nostalgia, el pensamiento y la libertad; neomahŷarí, por ende, es la literatura cultivada por los escritores hijos de la emigración. Características de esta modalidad se encuentran en Pedro Martínez Montávez. Introducción a la literatura árabe moderna, capítulo IV, "Literatura del Mahyar".

3 La producción chilena de libros es la siguiente: Litoral celeste (1940), poesía; Los tres (1944), ensayo; Las bestias del duelo (1948), poesía; Walt Whitman, el visionario de Long Island (1953), ensayo premiado por la Sociedad de Escritores de Chile (SECh) y la Municipalidad de Santiago; Los sueños de Caín (1953), cuentos, uno de los cuales obtuvo el Premio Renovación del Ministerio de Educación; Elegia bajo la tierra (1955), poesía; Sonatas del gallo negro (1958), poesía; Los derrotados (1961), única obra de teatro; Leyendas del Cristo negro (1962), prosa poética; El libro de los astros apagados (1965), poesía, merecedor del Premio Alerce conferido por la SECh y el Premio Pedro de Oña otorgado por la Casa de la Cultura de la Municipalidad de Ñuñoa; Testamento sobre la piedra (1971), poesía. Los libros escritos y publicados durante el autoexilio del escritor en Venezuela son: El hombre y sus circunstancias (1981), crónicas, luego seleccionadas y reeditadas bajo el título de Crónicas Radiales de Mahfud Massís (1999); Llanto del exiliado (1986), poesía, premiado en el XII Festival Mundial de la Juventud en Moscú; Este modo de morir (1988), poesía, también distinguido por el Premio Municipal de Literatura "Augusto Padrón"; y Antología. Poemas 1942-1988 (1990). Póstumamente se dio a conocer en Chile el poemario Papeles quemados (2001).

4 Esta Generación reúne a escritores nacidos entre 1905 y 1919, o bien, entre 1910 y 1924 ó 1925, y abarca un número variado de integrantes, según las opiniones de diferentes críticos que se han ocupado del tema. La crisis mundial provocada por la Segunda Guerra Mundial, el drama de la Guerra Civil Española y los efectos económicos, políticos, sociales e ideológicos de éstos y otros sucesos, crearon, en su conjunto, un clima de profunda inquietud en los intelectuales de todo el orbe. En Chile, las estructuras políticas y sociales chilenas 
pero fue un escritor que se apartó de la tradición e intentó dar forma a una propuesta poética propia, con fuerte impronta surrealista.

Como señala Naín Nómez, "un caso aparte lo constituye Mahfud Massís, un poeta singular con vertiente estética propia, aunque también entronizado en un despliegue que alude tangencialmente a las vanguardias, pero que periclita en un lenguaje más directo, de cuño existencial y vital que critica fuertemente una realidad urbana cada vez más alienante" ("La poesía" 88). La producción literaria de Mahfud Massís, junto a la de otros autores del 38, se constituyó, en alguna medida, en una segunda vanguardia, con un modo específico de poetizar ${ }^{5}$. En efecto, este escritor mantuvo, en un comienzo, una actitud de observador ante la atmósfera de inquietud que reinaba en el país, durante el advenimiento del Frente Popular. La problemática social y los anhelos de cambios en la vida nacional se manifiestan en sus artículos publicados en la revista Polémica $^{6}$, con los cuales se incorpora a aquellos

entraron en un proceso de cambio con el advenimiento del Frente Popular y el triunfo de Pedro Aguirre Cerda, en las elecciones de 1938. La atmósfera de inquietud que reinaba en el país hizo posible aunar a muchos literatos -algunos formados en la tradición criollista- en torno al Frente Popular y a los organismos artísticos que le eran afines, como la Sociedad de Escritores de Chile y la Alianza de Intelectuales. Influidos por estos acontecimientos e integrados en las instituciones a la que ellos dieron origen, los escritores chilenos del 38 se interesaron por la problemática social y postularon una poesía de raigambre épica, de reflejos colectivos que exigía cambios en la vida nacional. Fue una tarea compleja: muchos de ellos tomaron conciencia de que Chile tenía una literatura en construcción, y su primera labor fue intentar una nueva retórica y, por ende, una nueva concepción de la literatura. Cabe señalar que hay críticos que no hablan de Generación de 1938, pero sí de tendencias: es el caso de Antonio de Undurraga; en cambio, Montes y Orlandi señalan que esta Generación, a la que denominan Generación de 1942 y que estaría integrada por escritores nacidos entre 1905 y 1919, ha tenido preferencia por lo nacional y se ha distanciado, con una actitud crítica, de la Generación anterior. En cuanto al crítico Čedomil Goić, él llama a esta Generación de 1942 o Neorrealista; en tanto, Antonio Campaña recuerda que a esta Generación de 1938 también se la llama del Centenario, porque reúne a autores nacidos entre 1910 y 1920, esto es, a un número de integrantes cuyo nacimiento coincidió con la fecha en que se celebraba un siglo de la Independencia de Chile. Cabe mencionar que el escritor Gonzalo Rojas ha conformado grupos estéticos surgidos de la Generación del 38. Para él, el Grupo Rokhiano -signado con el número 8- "con centro en la Revista Multitud, fundada y dirigida por Pablo de Rokha", está integrado, entre otros, por Mahfud Massís y Julio Tagle. Sin embargo, y por diversas razones, no todos los críticos incluyen el nombre de Mahfud Massís en esta Generación.

5 Véase Naín Nómez, "Introducción".

6 De formato pequeño, la revista Polémica tuvo dos épocas bien definidas: en la primera se publicaron diecisiete números, entre octubre de 1953 y octubre de 1955, bajo la dirección 
escritores que tenían conciencia de que Chile poseía una literatura en construcción,--según señaló Volodia Teiltelboim en su artículo- esto es, que el país carecía de literatura propia en relación con las grandes literaturas europeas, y estaba en una búsqueda estética organizada en tres direcciones, a saber: 1) creación de una literatura contraria a la retórica y la poesía tradicional; 2) producción de una literatura popular, donde el hombre desposeído fuera el prototipo; 3) inclinación por una nueva retórica -sintetizando los dos puntos anteriores- con un lenguaje libre, directo e interpretando o creyendo interpretar al pueblo? .

En rigor, Massís no asumió todas estas orientaciones desde su perspectiva creativa, puesto que no se alejó totalmente de la retórica y poesía tradicionales. Así, su primer poemario Litoral celeste en parte se inserta en la tradición de la Generación del $27^{8}$; más aún, en casi todas la demás obras poéticas

de Mahfud Massís y Julio Tagle. La editaban en diferentes imprentas y ocupaban la casilla del clan rokhista (es decir, la n ${ }^{\circ} 13973$, de propiedad de Pablo de Rokha) para la recepción de los artículos; en la segunda época se publicaron alrededor de doce números, entre marzo de 1963 y abril de 1964, y sus directores fueron Mahfud Massís, Tito Stefoni y Julio Tagle (este último participó solo nominalmente); la administración estuvo a cargo de Erasmo Pizarro y la editaron en la imprenta Arancibia Hermanos.

7 Concluía Teitelboim que esta Generación no fue capaz de proyectar una literatura con más "claridad sobre la aventura humana", y tampoco pudo reflejar mejor el sentimiento de la vida y de la humanidad, con un sentido más propio.

8 La denominación Generación o Grupo del 27 se originó cuando varios escritores españoles se reunieron en el Ateneo de Sevilla para rendirle un homenaje a un poeta prácticamente olvidado a principios del siglo XX, don Luis de Góngora y Argote de cuya muerte se cumplían, en 1927, trescientos años y, también porque se le reconocía como un emblema de la renovación esteticista y neobarroca. Al mismo tiempo, estos poetas deseaban señalar que su atención iba dirigida a todas las innovaciones aportadas por las vanguardias artísticas de ese momento. Cabe señalar que se la ha conocido como Generación del 25, porque ese año comienzan los grandes éxitos de algunos de sus miembros; es el caso de Gerardo Diego y Rafael Alberti que compartieron el Premio Nacional de Literatura, pero esta fecha se rechaza porque algunos de sus poetas más representativos, como Aleixandre, Cernuda y Guillén, no han publicado todavía ningún libro; también se la ha llamado la Generación del 21 o del 23, porque en ambas fechas publicaron sus libros García Lorca y Alonso y, luego, Bergamín, Diego, Salinas y Espina; sin embargo, estas fechas son rechazadas porque se las considera muy parciales; por otro lado también se la conoce como la Generación Guillén-Lorca, que para la crítica es muy restrictiva, aun cuando los autores mencionados hayan marcado derroteros vanguardistas fundamentales; otras veces se la ha nombrado como la Generación de la Dictadura, debido a que la formación y primeras publicaciones del grupo coinciden con la Dictadura de Primo de Rivera en España -de 1923 a 1929; no obstante, esta denominación 
cultivó el soneto e, incluso, formas tradicionales, como el estilo versicular en Leyendas del Cristo Negro, o la balada y el ritornello, en su libro póstumo. La ruptura más evidente que lo alejó de la Generación del 38 radica en la creación de un lenguaje poético sui géneris que sustentó particularmente su obra lírica; por ende, no reflejó una literatura popular, sino que, por el contrario, construyó una escritura compleja, con la cual forjó determinadas imágenes y símbolos tradicionales y existencialistas, con un uso predominante del versolibrismo, además del cultivo de la prosa poética. El compromiso del escritor con respecto a la contingencia política, social y artística se encuentra en diversos artículos 9 .

Cabe destacar la lectura de impronta surrealista, titulada "Mandrágora, poesía negra" ${ }^{10}$, realizada por Braulio Arenas el 12 de julio de 1938, en la Biblioteca Nacional, en la cual instaba a los escritores a adoptar una definida modalidad estética, un compromiso efectivo ante los problemas sociales y políticos, o a explorar las dimensiones profundas de la conciencia. Al parecer, Mahfud Massís asistió a tal evento, pues en esos años residía en Santiago y conocía a los integrantes del grupo Mandrágora (fue amigo de Teófilo Cid y Gonzalo Rojas). Sin duda que, cuando conoció la declaración de principios

se ha considerado también impropia, porque la mayoría de los integrantes eran liberales; para algunos, se trata de la Generación de la Vanguardia, debido a las influencias recibidas tanto de las vanguardias europeas -futurismo, dadaísmo y surrealismo- como de las españolas -creacionismo y ultraísmo; para otros, es la Generación de la Amistad, por las afinidades que había entre la mayoría de sus miembros; y, algunos la designan como la Generación de los Poetas-Profesores, puesto que algunos de ellos se dedicaron a enseñar, como Salinas, Guillén, Diego y Cernuda. Cabe destacar que la propia Generación se autodefinía como La Nueva Literatura o La Joven Poesía.

9 Principalmente publicados en la revista Polémica, en la cual el escritor propuso que el pueblo debería educarse para apreciar el arte, la estética y la poesía, en tanto que a los artistas e intelectuales les correspondería aprehender del pueblo su pureza y dignidad, para recreárselas y, así, contribuir a su formación integral.

10 Véase Mandrágora - Retablo de literatura chilena en internet: http// www.mandragora. uchile.cl. La revista Mandrágora publicó en Santiago de Chile siete números entre 1938 y 1943. Y, según, Ismael Gavilán, “... sus miembros permanentes fueron Braulio Arenas, Teófilo Cid y Enrique Gómez Correa sin perjuicio que en distintos números apareciesen otros poetas tanto consagrados y conocidos como Huidobro o recién iniciando su aparición en el contexto poético de la época como Gustavo Osorio y Jorge Cáceres. Este grupo de autores, sobre todo los tres primeros, proponen un proyecto poético que buscaba su filiación con el movimiento surrealista internacional que André Bretón, junto a Paul Eluard, Louis Aragon y otros habían fundado en París en 1924..." (Gavilán, "Caracterización de la Generación del 38”). 
del grupo Mandrágora, se potenció en el autor el cultivo del tema de la muerte, con un modo específico de poetizar. Sin embargo, Massís no fue un seguidor riguroso de este grupo; solo adhirió a algunos de los postulados de la "poesía negra" de los mandragoristas, que le permitirán, a la postre, definir su perfil creativo. Se recordará que Braulio Arenas propuso las nuevas orientaciones de la "poesía negra", señalando que la poesía es:
... negra como la noche, como la memoria, como el placer, como el terror, como la libertad, como la imaginación, como el instinto, como la belleza, como el conocimiento, como el automatismo, como la videncia, como la nostalgia, como la nieve, como la capital, como la unidad, como el árbol, como la vida, como el relámpago... (Cit. en Meyer-Minnemann y Vergara 53-54)

Massís, sin duda, asumió una parte de este concepto de "poesía negra", para crear una lírica más personal e íntima, con una nota de misterio y oscuridad, en su producción escrituraria, particularmente en los libros de poesía. En efecto, estos presentan un tono fatalista, invadido de imágenes atávicas, donde el sentido de lo trágico incursiona entremezclado con el misterio de la muerte. Por consiguiente, esta proposición mandragorista de que "la poesía es negra", con un carácter enigmático y disolvente, facultó de algún modo al escritor a sumergirse en las profundas zonas de las tinieblas para auscultar el enigma de la muerte, transformándola poéticamente en su escritura. En este sentido, Massís se acerca y hace propia la definición de terror propuesta por Braulio Arenas:

... El terror es el sentimiento instintivo del hombre, que le empuja a buscar, alejándose de toda preocupación inmediata, la raíz genérica de su destino en las fuentes secretas del subconsciente, y encontrar ahí valiéndose del hilo conductor de la poesía, la relación estrecha entre su vida y los fenómenos del sueño, de la vigencia, de la locura, etc., que se escapan a un control diario, empleando para ello y como soluciones POÉTICAS, todos los recursos que tenga a su alcance como ser el delirio, el automatismo, el amor, el azar, el crimen, y, en general, todos los actos sancionados por la ley, por la medicina y por la religión... (Cit. en Meyer-Minnemann y Vergara 54) ${ }^{11}$.

11 La mayúscula pertenece a la cita. 
Efectivamente, en la génesis del cultivo del tema de la muerte, Massís atravesó por varias etapas conectadas de algún modo con esta definición de "terror": primero, lo absorbió el dolor y la ausencia que le produjo la muerte de cada uno de sus seres queridos; segundo, se estremeció de miedo y horror al imaginarse la realidad descarnada de la desintegración de los cuerpos; tercero, su ateísmo le llevó a poner en duda la existencia de la divinidad y de la vida eterna y, en consecuencia, asumió que las almas iniciaban un eterno deambular. El resultado de esta experiencia de "terror" en Massís es la proposición de una muerte que subyuga, produce espanto y funda un drama interior en el que vida y muerte cohabitan en el hombre. Luego, el poeta construye un infierno para desafiarlo, desciende en él porque está convencido, paradójicamente, de que es su único derrotero y permanece en él, en esa instancia de horror y aniquilamiento, porque es allí donde se siente vivo. Se puede deducir, entonces, que la muerte es una suerte de "terror massisiano" y, como dice Braulio Arenas, “...le empuja a buscar...la raíz genérica de su destino en las fuentes secretas del subconsciente..." Estas "fuentes secretas del subconsciente" son las que le han conferido a la lírica massisiana un derrotero órfico y un orientalismo panteísta y lúgubre, las que se pueden observar en las imágenes antisolares de este estudio.

La primera obra poética, Litoral celeste, ${ }^{12}$-estimada por Massís como un pecado de juventud y, por consiguiente, ignorada en su Antología ${ }^{13}$ - concentra embrionarias imágenes de la muerte, las cuales anunciarán su desarrollo ulterior como tema predilecto y fundamental del poeta.

Pero, a partir de la publicación de Las bestias del duelo comenzó a explorar las dimensiones profundas de la conciencia y a subjetivar la deshumanización del mundo, creando, entonces, una poesía en la que predomina el habitar un mundo caótico, apocalíptico y de absolutas tinieblas. Cabe destacar que la experiencia de la muerte y del exilio -que es otra manera de morir y que sufrió el escritor en Caracas ${ }^{14}$ - invaden todo el escenario poético massisiano,

12 El autor se firmaba como Antonio Massís en Litoral celeste.

13 Este poemario fue revisado y corregido por el propio autor. Además, contiene Leyendas del Cristo Negro, prosa poética (no considerada para este artículo); “Ojo de tormenta/ 19601989" (poemas publicados en plaquetas o insertos en la revista Polémica,) y "Escrito hace cincuenta años", un compendio sobre su teoría de la imagen poética.

14 El 11 de septiembre de 1973 se convirtió en una fecha aciaga para todos aquellos chilenos que colaboraron con el gobierno de Salvador Allende, y su derrocamiento significó 
integrado, además, por Elegía bajo la tierra, Sonatas del gallo negro, El libro de los astros apagados, Testamento sobre la piedra, Llanto del exiliado, Este modo de morir, Antología, los cuales se caracterizan porque están pletóricos de angustia, dolor y pesimismo, para transformarse, en el poemario póstumo, Papeles quemados, en una escritura fragmentada, lúdica, sarcástica e irónica, como reflejo de un desarraigo destructivo, personal y colectivo de su autor.

Asimismo, todos estos libros contienen manifestaciones anticlericales, donde la nostalgia del paraíso perdido se transforma en una búsqueda ancestral de lo árabe y una reivindicación de la tierra jerosolimitana. El conjunto de estos rasgos estructurales y temáticos permiten sostener que la producción lírica massisiana, en rigor, no se relaciona cabalmente con los presupuestos teóricos de la Generación a la cual pertenece, si bien conserva -eso sí- una dimensión oscura y pesimista, debido a que el escritor comenzó a construir un proyecto poético propio y definido, con una atmósfera atormentada y una visión desintegradora. De tal manera que la lírica massisiana, por un lado, tiene carácter personal, derivado de las circunstancias familiares dolorosas y la desaparición de sus amigos y camaradas ocasionadas por el régimen militar; por otro, está relacionada con el ámbito exterior, pero que también incide y compromete su percepción poética, pues está vinculada con la angustia que le produjo la deshumanización del mundo, los conflictos bélicos $\mathrm{y}$, especialmente, la ocupación de la tierra ancestral ${ }^{15}$.

para muchos la cárcel, la tortura, la muerte y la desaparición; para otros, el destierro o, como prefirió Mahfud Massís, el autoexilio, mientras ejercía el cargo de Agregado Cultural en Venezuela.

15 En el plano familiar, lo afectó profundamente la agonía de sus dos jóvenes hermanos Hafìz yHāfiz muertos de tuberculosis (1937 y 1943, respectivamente); la muerte de su padre Farhan Massís (1947), a consecuencia de la diabetes, y de su suegra, Winett de Rokha (1951), debido al cáncer; la muerte o suicidio de su cuñado Carlos (1962). Luego la muerte de su otro cuñado, Pablo (1968), y el suicidio de su suegro, Pablo de Rokha (1968) y, más tarde, el deceso de su madre, Rauda (c.1986), mientras permanecía en el autoexilio, en Venezuela. En el plano nacional, lo impresionaron los problemas políticos y sociales de la nación, sobre todo los derivados del régimen dictatorial de Augusto Pinochet; esta situación se añade a su propio desarraigo cuando optó por el autoexilio. Finalmente, en el plano internacional, observó con atención los efectos de la Guerra Civil Española y de la Segunda Guerra Mundial, como asimismo los problemas no resueltos del Medio Oriente y, en particular, la crisis del pueblo palestino, que lo afligió íntimamente porque le reactivaba la memoria latente de la tradición de sus ancestros árabes. 


\section{MASSÍS Y LA IMAGEN POÉTICA}

La presencia de la muerte en los poemarios massisianos está transida de una impronta trágica, violenta y dramática. Los espacios se envuelven en nieblas pantanosas, umbrías y viscosas en la medida en que el poeta desea expresar una síntesis de instantes de dolor, separación y soledad y, al mismo tiempo, quiere señalar que en él conviven el ayer, el hoy y el mañana, instancias témporo-espaciales que muestran una determinada visión del universo, en la cual impera un silencio cósmico. Para Massís, a través de esta triple tesitura y simultaneidades de instantes metafísicos emerge

La imagen, vehículo fundamental de la poesía, alcanza su mejor designio en la conjunción de dos identidades remotas. Entre ambas se mueve la membrana acuosa de lo incognoscible, ya que la imagen, como síntesis, rehuye [sic] toda explicación, todo proceso....Mientras mayor sea la distancia entre los elementos que constituyen la imagen, mayor será también la radiación que origina aquella emotividad de los encuentros ignorados... (Massís, Antología 276).

De algún modo, esta teoría de la imagen poética de Massís está en relación con la verticalidad profunda, a partir de la cual se origina el instante poético de Bachelard:

En esencia, el instante poético es una relación armónica de dos opuestos. En el instante apasionado del poeta hay siempre un poco de razón, en la recusación razonada queda siempre un poco de pasión. Las antítesis sucesivas gustan al poeta. Mas para el encanto, para el éxtasis es preciso que las antítesis se contraigan en ambivalencias. Entonces surge el instante poético...El instante poético es cuando menos conciencia de una ambivalencia. Pero es más, porque es una ambivalencia excitada, activa y dinámica. El instante poético obliga al ser a valuar y a evaluar. En el instante poético, el ser sube o baja, sin aceptar el tiempo del mundo que reduciría la ambivalencia o la antítesis y lo simultáneo a lo sucesivo...." (La intuición del instante 90).

En esta perspectiva se presenta una irrefutable coincidencia en ambas proposiciones sobre la imagen poética, puesto que en Massís acontece en un tiempo donde se privilegia la verticalidad hacia abajo, es decir, para él la creación 
es en un comienzo "monstruosa"16; el drama poético de la muerte brota con violencia del reino de la oscuridad, en el que el poeta, como señala Bachelard en La intuición del instante, "siente la ambivalencia abstracta del ser y del no ser" (93), debatiéndose entre instancias de tinieblas que estimulan el dolor y la soledad. Pero Massís añade algo más: él necesita revivir la experiencia de la muerte y, para alcanzar tal objetivo, realiza un itinerario subterráneo hasta llegar apenas a una superficie, para luego volver a sumergirse en ensoñaciones de recuerdos encadenados, preteridades ausentes, esperanzas perdidas.

La escritura poética massisiana está construida a base de "un lenguaje descompuesto", heredado de sus antepasados y de la percepción de la materia violentada por la realidad de la muerte, la disolución del cuerpo, la desintegración del ser y una búsqueda casi siempre infructuosa de la trascendencia. Según el autor, esta poesía funda el "monumento funerario de mi época" (Massís, Las bestias del duelo 11-14) ${ }^{17}$.

Sin embargo, esta inclinación a versificar sobre la muerte no solo proviene de los ancestros del autor, quienes "...me legaron una carga mortal que no consigue superar mi condición de retoño americano...” (Massís, Elegía bajo la tierra, $\mathrm{s} / \mathrm{p}$ ); también reconoce que es un poeta nacido en un continente escenario de encuentros y desencuentros sangrientos: “...Pero América ¿no es acaso un dolmen gigantesco en donde los ritos de la sangre todavía

16 Massís afirma que precede a todo acto creador un aspecto confuso, indefinido, amorfo, semejante al caos pre-genésico bíblico. Y es ese carácter monstruoso, embrionario, informe y violento el que determina la creación de un poema “... Porque es necesario saber que la belleza lleva implícita una cualidad que la genera... Sólo así fue posible el culto de lo feo, de lo descomunal, de lo terrible. Cuando el poema no reconoce una razón interior profunda, es que estamos frente a un espécimen del arte por el arte..." (Las bestia del duelo 10). Sin duda que este autor fue -como muchos escritores de su Generación- un lector de los Cantos de Maldoror del Conde de Lautreamont. Las imágenes violentas, agresivas, excitantes, junto a las deformaciones producto de su libre voluntad creadora, evocaciones dolorosas y monstruosas transformadas en materia poética, entre otras, lo estimularon para traducir su propio mundo interior, preñado de imágenes de violentos misterios donde el tema de la muerte se torna otra vez recurrente. Paradigma son sus cuentos fantásticos-existenciales, Los sueños de Caín.

17 Citas extraídas de "Condensación de carta estética. Fundamentos para una teoría del arte” que Mahfud Massís incluyó, a modo de introducción, en su poemario Las bestias del duelo. 
humean?..."18. Sin duda que para el autor lo árabe y lo latinoamericano están relacionados por el vínculo de la muerte.

Esta doble impronta mortal recubre su lenguaje poético, en el cual se fraguan imágenes crepusculares, instantes rescatados de la memoria, procedentes de la experiencia de la muerte que el poeta amasó en su inconsciente y que, en el momento de la creación, afloran cargadas y envueltas en negruras para construir el tema de la muerte. Asimismo, esta escritura se convierte en una interrogación lúdica a un origen perdido del cual emanan fatalmente la adversidad del destino humano. Massís bucea en sus dominios ancestrales, recupera su materia primigenia, informe y abismal y crea su imagen poética, su "hecho cruento que persiste en la memoria con la violencia de su impacto emotivo" (Massís, Elegía bajo la tierra, s/p) ${ }^{19}$. El poeta se expresa a través de esta imagen poética; la protagoniza en una sola idea -el tema de la muerte- que fluye en una lenta agonía y un padecer donde residen transformados los avatares inexplicables de una época. En rigor, propone el concepto de poeta-mesías que destila un mensaje poético procedente de su ser real y condicionado por los vaivenes de la historia.

\section{ALGUNAS IMÁGENES POÉTICAS}

Las imágenes poéticas de raigambres mesopotámicas, egipcio-faraónicas, palestinas y libanesas están relacionadas, en general, con el yo poético, los padres emigrantes, y los hermanos muertos del autor.

Debido a la fidelidad y la defensa del autor de su prosapia árabe, se puede comprender que una parte de su cultura vernacular la ha transmutado en materia poética, para originar ciertas imágenes de la muerte, pero forjadas con cuño propio. Así, para reafirmar su origen misterioso, lejano y fúnebre, el hablante lírico se desdobla y se presenta con la fuerza y agresividad destructivas de quien se rebela ante la divinidad, diciendo: "Soy Mahfud Massís,

18 En otro estudio se podrá observar, por ejemplo, la relación entre la poética de Massís, C. Vallejo y O. Paz.

19 Esta cita evoca la tesis del escritor Enrique Gómez Correa, quien afirmó: “...quiero ser pensamiento puro; quiero ser puro acto, puesto que todo principio está en la violencia. En síntesis: en un comienzo fue la violencia". Véase "Enrique Gómez Correa", en Poetas chilenos del siglo $X X, 321$. 
el Esclavo,/ el heresiarca de piel negra,/ ...Escondo mis dientes de cabro, mi cola de rey babilónico,/ mientras camino por la ciudad, junto al angosto río./ Entre lívido aceite, mi vieja sombra atraviesa las ciénagas,/ ladrando a la majestad lunar..." (Massís, Antología, "Poema 3", 35).

En varios poemas, el hablante lírico se asume cual cadáver errante que cruza la ciudad-cementerio, donde destacan las tumbas y la descomposición. En este contexto, se compara con el cadáver de Gilgamesh ${ }^{20}$ : “...Entre roncos atambores, mi cadáver atraviesa la ciudad/...Tu cabeza agusanada salta dentro de la copa de anís,/ te pudres lentamente, mientras todos yacen dormidos/ en la casa,/ (un gallo corre en el dormitorio ensangrentado); y galopas, como el fantasma de Gilgamesh bajo los zócalos...”(Massís, Antología, "Poema 13", 45). Y en otro poema, el yo lírico se compara con el espectro de Gilgamesh, unido al mito de Ofelia ${ }^{21}$-aunque de ella solo se conserve una sinécdoque-, porque ambas imágenes son sustentadoras del dolor, la soledad y el sentimiento de muerte que conlleva el exilio: “...Me preguntan, cuando atardezco,/ por qué he dejado de respirar hundido en estas piedras,/ y hablo con los pájaros/ como el espectro de Gilgamesh entre las ruinas,/ evocando a la que lava sus guedejas/ a orillas del mar, o al que bebe/ sangre y desencanto..." (Massís, Antología, "I", 129).

Las imágenes tanáticas egipcias se presentan con cierta frecuencia en los poemarios massisianos. El mismo hablante lírico se proclama descendiente del faraón Amassis 22 “....mi pariente definitivamente seco..." (Massís, Antología, "Subasta" 123). Así, esta voz lírica, desde una condición de difunto que deambula y recuerda bajo el firmamento a Osiris, a Isis, entre otros dioses, declama: "Estoy muerto, pero me crece la barba./ Muerto, entre reses de plata

20 Como se sabe, este héroe mítico asirio-babilonio ejemplifica la actitud del hombre frente a la muerte, la repulsa ante la descomposición y el deseo de vencerla, procurándose una gloria inmortal. Pero, en el poema, la mención a Gilgamesh solo acentúa la angustia existencial de quien no supera la inmortalidad y vaga eternamente en el subsuelo. Véase a Noah Kramer. La historia empieza en Sumer.

21 Personaje shakesperiano de la tragedia Hamlet.

22 En rigor, en la historia de Egipto hubo un rey Amasis que reinó entre 568-525 y perteneció a la dinastía XXVI (663-525 a. C.). Su reinado fue pacífico y próspero; sus fronteras - eso sí- estaban amenazadas por la invasión. Véase Étienne Drioton, Jacques Vandier. Historia de Egipto. Buenos Aires, EUDEBA, 1964, pp. 496 y ss, y notas. También Herodoto destaca del rey Amasis su diplomacia, su vida alegre y juerguista. Véase Herodoto. Los nueve libros de la historia. Libro Segundo "Euterpe", capítulos CLXXII-CLXXXII. 
mojada, entre/ enredaderas y sepulcros./... Evoco la memoria de mis viejos dioses, tuertos o/ licenciosos, / ... pero envejece mi rostro como las culebras, / y escucho el paso de las momias, pesado como oso..." (Massís, Antología, "Poema 19", 51). También la voz lírica apela a la muerte que lúdicamente está "... bajo un palio de rosas descompuestas,/ entre los sicomoros y los castaños..." (Antología, "Poema 20", 52); pero también el yo lírico se dirige a un tú para indicarle que la muerte "Junto a los sicomoros te espera su sombría belleza/... Su cabeza de fiera resplandece,/ recuerda el espanto de un rey muerto hace miles de/ olvidados años..." (Antología "Poema 22", 54). La indefensión se apodera del yo lírico cuando se ausenta esta belleza mortal: “...Y yo preguntando tu dirección, averiguando tu nombre,/ la imagen de tu destrozada beldad/ entre los sicomoros quemados" (Massís, Antología, "Destino" 106) $)^{23}$.

El hablante lírico adquiere un talante hierático egipcio mientras “ . . fumo mi pipa como un pope rojo,/ .... echo humo sobre mis obsesiones funerarias..." (Massís, Antología, "Nocturno de la pipa" 64) y, luego, apela a la divinidad invocándole como “...Padre Muerto, distíngueme entre la arena. ¡Levántame!/ Deja caer tu mano seca en mi cuello. Tu cordel seco, Tu hueso seco...Señor de los Difuntos, tú que controlas el sueño,/ la menstruación de la mujeres,/ tú que matas en la cuna al infante..." (Massís, Antología, "Salmo cero" 75). Asimismo, el yo lírico se apodera de la imagen de Osiris, como dios de la resurrección, para predecir que su estro creador perdurará más allá de la muerte: “...Desenterrarán tus cartas, tus papiros helados./ Serás como Osiris; se disputarán tu traje desolado./ Sobre tus infolios y tus manchas errantes: la leyenda..." (Massís, Antología, "El desenterrado" 102).

Incapaz de vencer a la muerte, el hablante lírico se entrega desolado y trágico a un tribunal divino para que resuelva sus angustias. Se trata, por una parte, del tribunal consagrado en el Libro de los Muertos ${ }^{24}$ egipcio y destinado

23 Se puede advertir que el poeta crea un tópico significativo entre la muerte-belleza y el sicomoro que es, además, un símbolo del árbol de la vida. "Sicomoro o sicómoro. M. Planta de la familia de las Moráceas, que es una higuera propia de Egipto, con hojas parecidas a las del moral, fruto pequeño, de color blanco amarillento, y madera incorruptible que usaban los antiguos egipcios para las cajas donde depositaban a las momias" (DRAE).

24 Hay una profusa bibliografía sobre el panteón egipcio antiguo. Se cita aquí una fuente que, sin duda, el autor leyó y la convirtió en materia poética, esto es, El Libro de los Muertos. Véase el estudio preliminar, traducción y notas de Federico Lara Peinado. 
a que el difunto no yerre su ruta hacia la eternidad e instruya al alma sobre lo que debía hacer después de la vida y, por otra, es el Juicio Final de la religión cristiana. Sea cual fuere, el hablante lírico satiriza este ámbito: "Entrego mi cabeza al tribunal,/ con sus ensueños, sus estreptococos,/ quiero librarme/ del ángel/ que me arroja a estos dominios./ ¡Basta ya de/ esparadrapos, de antiguas navegaciones!/...Me entrego/ voluntariamente/ para trabajar en la cocina, o preparar/ venenos silenciosos, / con aquel joven tullido,/ o esa gran dama vestida de blanco/ que es una gallina ciega" (Massís, Antología, "Rendición" 169).

Ironía y mofa ante la muerte irremediable se advierte en el hablante lírico cuando desacraliza la imagen del cocodrilo sagrado - que para los egipcios era un símbolo del devorador de las almas condenadas-, agregándole un significado sarcástico, pues representa al dictador Augusto Pinochet: “¡Estaba Muerto!/ me echaron la meada en la oreja./ Debía enfrentar al Gran Cocodrilo./ Colgaba de la pared./ Era un asbesto..." (Massís, Papeles quemados, "Error contable" 74).

Imágenes palestinas y libanesas vinculadas con el tema de la muerte se presentan desde varias perspectivas. El hablante lírico desentraña y hace suyo el esfuerzo, el dolor, la discriminación que sufrió el inmigrante árabe en su oficio de falte ${ }^{25}$ o buhonero y los convierte en poesía de desencanto y muerte: "Paseo mi espanto por la ciudad; el guardia/ del cementerio me reconoce, los vagabundos, los azules/ gusanos de la noche... Fui vendedor de cirios, de muertos sin identidad, vendí/ cerveza, /fui comprador de grandes pipas funerarias..." (Massís, Antología, "Poema 2", 34). Consciente de que el abandono, el desarraigo y el dolor por la partida del terruño natal marcaron la existencia del árabe inmigrante, nuevamente el hablante lírico transforma esta experiencia en una adiós definitivo, cercano a la muerte: “¡Qué día corazón! ¡Qué noche! Partió/ el árabe, marchito, pobre, siempre lejano como su padre./ Deja sólo/ una escoba, un candil, un pan duro para la quijada de la muerte./ Un libro antiguo al fondo de la noria..." (Massís, Antología, "Adiós" 107).

25 "Falte. m. pop. desus. Buhonero, mercader viajero... Según Román, proviene del grito del buhonero ‘¿Hay algo que falte? [se entiende, en la casa]. Véase, Félix Morales Pettorino. Nuevo diccionario ejemplificado de chilenismos, p. 1123. 
También la emigración y el exilio son experiencias similares que se transforman en sinónimos de soledad, dolor y muerte. Así, el escritor en Caracas ${ }^{26}$ revive líricamente este destierro análogo al de su ancestro árabe: "Poseo la tristeza del mercader/...Partí a América./ pero nadie entendió los signos del proscrito,/ nadie identificó mi sombra/ y no queda/ sino este trozo de lengua/con que predico en el mercado..." (Antología, "XV", 143). La condición de exiliado y de sentirse extraño en el mundo representa para el escritor un modo de morir, y sentir la soledad en tierra lejana le hace evocar, en varios poemas, el sentimiento que con certeza experimentó su padre inmigrante, cuando añoraba el regreso imposible a Palestina. Solidario con este dolor paterno, la voz lírica exclama en los siguientes versos: "Padre: me arrojaron en este pozo./ ¡No hay ámbar ni Dios que pueda salvarme! ¡Sólo hiedra!/... Yo/ que salí de tu primer/ hueso en esta pobre América,/ no supe comprender,/ preguntabas, apenas,/ por qué estamos aquí.¡Qué lejos está Palestina! Y yo sólo/ quería llorar/...Quisiera, si es posible,/...Poder decir: marchemos juntos a Palestina./ pero ella ya no está, y tú y yo andamos perdidos" (Massís, Antología, "XXII", 152).

Resabios de la imagen feroz del árabe del desierto todavía perduraban en el poeta cuando sobrevivía redactando crónicas para Radio Nacional de Caracas $^{27}$. Así, el hablante lírico se vanagloria: "Siete mil/ veces estuve/ en el aire/ de Radio Nacional/... Con ustedes el poeta Mahfud Massís, declamaba/ una voz oceánica. Puede hacer reír o llorar,/retorcerse de gozo, como un mago/ recién llegado de Calcuta./ Dejaba caer entonces el ácido en diminutas/ gotas, o en flores de lis,/ y todo/ residía en mi lengua de sarraceno,

26 Véase nota 14.

27 La instauración de un nuevo régimen en Chile, en septiembre de 1973, determinó que Massís, conocido como afamado diplomático, escritor y conferencista, se convirtiera en un cesante ilustrado y apátrida. Este fue el destino de Mahfud Massís cuando decidió optar por el autoexilio y vivir en Venezuela. Cabe señalar, entre otros trabajos que realizó para subsistir, su participación con un breve programa radial llamado "El hombre y su circunstancia" en la Radio Nacional de Venezuela, cuyos breves relatos de impronta satírico-humorística fueron publicados bajo el título El hombre y su circunstancia. Crónicas. Caracas, Grafeín Editores, 1981. Posteriormente se publicó una selección de esta edición, además de otras crónicas radiales, bajo el título La radio de MM. Crónicas radiales de Mahfud Massís. Santiago de Chile, Imprenta Salesianos, 1999. Esta publicación, a diferencia de la anterior, consta de veinticinco relatos. 
disfrazado de juglar, de pobre armadillo..." (Massís, Papeles quemados, “Ácido en el aire" 84).

El hecho palestino ${ }^{28} \mathrm{o}-\mathrm{el}$ conflicto árabe-israelí- a veces se inserta poéticamente con imágenes de factura mordaz. De esta manera, el yo lírico exclama: "...Reduciré a los cobradores invocando a los dioses en la hora postrera,/ chupando una esponja, bebiendo vinagre, vinagre blanco si es posible,/ pero quiero enviar antes un telegrama a los editores,/ un cable a Palestina,/ donde mis antepasados orinan sobre el Santo Sepulcro" (Massís, Antología, "Elegía sin hueso" 65). Sin embargo, consciente de que la tierra jerosolimitana es un escenario de muerte, el hablante lírico recrea con hondo pesar este sufrimiento: "Ciertos muertos me saludan, vienen/ de Palestina,/ preguntando cómo y por qué, llorando,/ mientras cae la lluvia y llenan sus cántaros diciendo adiós/ entre églogas y responsos temibles..." (Massís, Antología, "XI", 139). Un sentimiento de dolor e impotencia se incrementa cuando Palestina -y toda la tierra árabe por extensión- es ambicionada no solo por el símbolo que ella contiene, sino también porque en la región se encuentra el petróleo, ese tesoro ambicionado que ha convertido la tierra árabe en un escenario de muerte y desolación. Entonces el yo lírico invoca: "Cubiertos de crestas de gallo,/ sus antepasados cuelgan/ en el Muro/ de las Lamentaciones./ Poseen/ una funeraria,/ y una torre/ y ruedas. Por esas frentes, por esos terribles agujeros,/ fluye el petróleo entre las piernas finas,/ sobre sus muertos/ tristes/ como atletas conservados en aceite..." (Massís, Antología, "Petróleo" 109).

La muerte de la madre libanesa, ocurrida mientras el poeta vivía el exilio y sin que pudiera estar presente para su sepelio, es recreada en imágenes evocativas. Así, la voz lírica, transida de abatimiento, dolor y nostalgia, declama:

28 Dos acontecimientos son claves en el hecho o tema palestino: primero, la declaración del Estado de Israel, el 15 de mayo de 1948 y la simultánea ocupación de los territorios palestinos. Este desastre se denomina An- Nakba (La Catástrofe); segundo, la gran derrota árabe de 1967, conocida como La Guerra de los Seis Días y, en el mundo árabe, como AnNaksa (La Recaída, El Retroceso). Precisamente este último acontecimiento determinó, entre otros factores, la creación y el desarrollo de la llamada "literatura palestina resistente", cuyos rasgos definitorios son el compromiso, el carácter combativo, la denuncia y el testimonio. Algunos de los representantes más destacados son: Fadwa Tuqan (1917-2003), llamada "la poetisa de Palestina"; Mahmud Darwish (1942-2008), Samih Al-Qasim (1939 - ). Véase, por ejemplo, a Pedro Martínez Montávez, "Desde 1967: La expresión de un desastre”, 251-288, y, en especial, la página web www.poesiaarabe.com 
"Con un tambor y un poco/ de hierba negra,/ pienso/ que cualquier lugar es bueno para morir./ Pero hoy, qué tristeza,/ que ganas de morder las piedras, porque hoy,/ precisamente hoy,/ mi pequeña madre ha muerto en su casa de Santiago,/a diez mil kilómetros de aquí,/a un millón de mis manos que envejecen cada tarde.../...Otros hijos/ viste/ destrozados/ o caídos en la noria, triturados o carcomidos o sedientos de púrpura,/ como vasos reventados en la frente/ de un dios..." (Massís, Antología, "VI", 134). En otros versos, el yo lírico se lamenta por la madre ausente, buscando un remoto consuelo, ya que la divinidad no le responde: “... Madre: vestido de pordiosero te llamé esta madrugada./ Te habías ido/ por aquella ciudad en que se llora y anda desnudo.../ Pero lo sabes: viví con escaso/ ropaje y comidas/ frías.¡Me mató un toro negro!/ Me llamaron/ el extranjero.../... arrojo una golondrina muerta/ contra el cielo, preguntando a Dios/ quién soy, ¡Y me responde un aullido!” (Massís, Antología, "XVI", 144).

Un sentimiento angustioso y un desgarrado lamento se conjugan en visiones simultáneas de soledad y muerte, para mostrar, por un lado, a Palestina y El Líbano destrozados por la guerra y, por otro, el destierro del poeta de su patria, que está en "la boca del tiburón", o sea, Pinochet. Todas estas imágenes se unen finalmente al recuerdo de la madre, mientras el hablante lírico yace sometido y extenuado de dolor y muerte: "La verdad, no tengo de dónde agarrarme a veces./ Pienso que estoy ciego, que todo/ fue abortado/ y Palestina cuelga su último muerto/ en el olivar./Y tú, Líbano/ de las maderas resonantes, cómo fuiste/ asolado. Mi sangre/ está ahora en la viscosa boca del tiburón. / ¿Y Chile? ¿Qué piedra! Ah, ya no tengo pasado,/ y no puedo volver.../... Escucho una multitud, un alarido que reconozco,/ como reconocería un dedo/ cortado, o tu propio/ rostro, madre, cuando te morías/ y yo estaba en Caracas/ esperando el diluvio sentado en una tinaja negra" (Massís, Antología, "XVIII", 146) ${ }^{29}$.

La profunda impresión que le causó el deceso de sus dos hermanos tuberculosos fue una experiencia trágica, alejada de toda resignación y sumisión ante el destino funesto y que el autor transformó en materia poética. Este desconsuelo familiar no solo le provocó un profundo pesar; también

29 Estos versos delatan una vez más la condición del escritor como autor-narrador y personaje que recrea poéticamente su doble exilio: el de sus padres de la tierra palestina y libanesa y el de su propio desarraigo de la tierra chilena. 
se sumó la percepción que tenía de un mundo destruido por la crueldad y la desolación. Para el escritor Massís, existencia y muerte conforman un solo corpus: vivir es morir y la muerte es una vivencia que se adelanta. Así, por ejemplo, en las imágenes poéticas relativas a la muerte de sus hermanos se exterioriza una evidente violencia del existir y el morir. El yo lírico se lamenta: “...Hoy ha muerto el último, y corro/ quebrándome los huesos para golpear tu puerta./ ¿No era aquél que tosía esperándote/ y sembrando la tierra de bacilos y rubíes..." (Massís, Antología, "Adelfa de los amantes muertos" 16). En otro poema, el hablante lírico acompaña al difunto y describe su soledad angustiosa como si fuera un reflejo de la suya: “...Estás solo, solo como los poetas y los moribundos./... Solo, está solo como un ladrón de muertos,/ solo entre ángeles enfermos y lagartos minerales..." (Massís, Antología, "Elegía deHāfiz" 74) $)^{30}$. Sin embargo, el hablante lírico insta al alma del muerto para que inicie una búsqueda de la trascendencia, como un alma egipcia en su barca-ataúd, en tanto él mismo llora porque el deceso de su hermano es la antesala de su propia muerte en vida: “...Bracea, bracea ahora a la eternidad en tu ataúd de raso... ¡Soy una estatua rodeada de perros,/ y lloro por ti arsénico y lágrimas venenosas que sujetan mi vida,/ y los huesos me crujen como féretros..." ("Elegía de Hāfiẓ”).

Desde otra perspectiva, el imaginario poético massisiano muestra las huellas de lecturas clásicas grecolatinas, en las cuales el poeta se ha inspirado para crear aquellas imágenes que expresan y develan la angustia de su época y una suerte de contradicción hombre-universo. Estas imágenes míticas representan el descenso constante del poeta hacia los límites de un averno que no siempre es exterior. En efecto, ese derrotero, esa opción límite del poeta se encuentran en el interior de sí mismo; es allí donde se siente vivo; es allí donde encuentra el no-ser, la muerte. A continuación, una selección de imágenes míticas con cierta impronta órfica, funeraria y lúgubre:

Prometeo y la muerte. La poesía de Massís está impregnada de una fuerza dinámica en que se consume el ser en una flama cuyo resplandor puede iluminar el cielo o el infierno ${ }^{31}$. Se puede postular, entonces, al autor como

30 En homenaje a la muerte del segundo hermano del autor (Ambos nombres se diferenciaban por un acento: Hafìz, el hermano mayor, su nombre en árabe significa "atento, "cuidadoso" "solícito"; Hāfiz, el hermano menor, significa "guardián”, “conservador”, "preservador”, "el que sabe de memoria”, especialmente El Corán).

31 Véase Gastón Bachelard. Fragmentos de una poética del fuego. 
un poeta del fuego, cuyo lenguaje está preñado de imágenes ígneas, a través de las cuales se violentan las significaciones. Es en el fuego donde el ser y el no-ser se consumen; pocas veces renacen, y sus fragmentos se irradian al infinito o al infierno. En este contexto, se han observado dos modalidades en el empleo de la imagen de Prometeo. Primero, el poeta realiza una versión de la figura trágica del héroe castigado en la montaña, además de integrar la figura mítica de Atlas (Bachelard, La tierra y los sueños de la voluntad 379-446) ${ }^{32}$. El hablante lírico se lamenta que en la hora de su muerte: “...mi cuello de atlas, de toro célico y joven,/ no podrá soportar mi cabeza vacía..." (Massís, Antología, "Adiós a los lobos" 22). Es decir, es un atlas menor: su peso es su cabeza y no el mundo. Y, a continuación, clama para ser transportado cual Prometeo a la montaña, mientras los buitres - no el águila mítica que devoraba el hígado eternamente regenerándose- se encargarán de distribuir sus fragmentos que iluminarán otros mundos: “... ¡Llevadme a la montaña, llevadme a la montaña!/ ¡Ay, seré un hombre muerto, un animal llagado!/ Dejadme en la montaña./ Los buitres, aves santas,/ en sus ancas letales y en boreal terciopelo/ me llevarán a todos los flancos de la tierra./ Mi harina podrida encenderá los últimos planetas absortos...".

La segunda modalidad de la imagen de Prometeo no responde, sin embargo, al héroe emblemático castigado por los dioses; se diferencia de él porque el escritor crea una versión muy particular del castigo del héroe. Precisamente la imagen básica del prometeísmo - robo del fuego divino y el águila devoradora- se dinamiza y se reduce a la imagen de un "hígado derretido". Se presenta, entonces, un hablante lírico prometeico inmolado por su afán poético de cultivar el tema de la muerte y que ha sido castigado; pero, ahora sin posibilidad de regenerarse, está a la espera de su viaje final: “¡Soy el Miserable que se ahogó en la poesía!/ Pude ser capitán, degollador de escualos,/ pero sólo fui cabeza de perro/ en la necrópolis de la Gran Ciudad./ Observo mi hígado derretido,/ mis/ poemas/ en las letrinas,/ en cuyo pórtico me espera una mula negra..." (Massís, Antología, "Penúltimo cartel" 118). En este poema se agrega también la imagen mítica de Atlas, vinculada a la imagen prometeica anterior. Pero aquí también se produce una ruptura en relación con la imagen básica del Atlas -soportar el mundo sobre sus espaldas-porque el

32 Véase Gastón Bachelard. "Tercera Parte. XII "La psicología de la gravedad”. En La tierra y los ensueños de la voluntad, especialmente pp. 401-414. 
hablante lírico prometeico se convierte en el mismo Atlas cargando varios objetos: “... En las espaldas/ cargo un huevo infinito, una/ pierna quebrada, / un piano que gime en la inalcanzable profundidad...". Este "huevo infinito" representaría un universo en simiente o en eterna renovación, mientras que la "pierna quebrada" y el "piano que gime" se pueden interpretar como la situación caída del ser humano.

El mito del Fénix. El poeta se convierte en un voyeur de la muerte en su tránsito hacia el infierno, donde ella habita. Entonces abre sus puertas para mostrar los abismos cuyas llamaradas suelen emerger con violencia hacia el cosmos. En este contexto, cabe señalar la presencia de la figura mítica del Fénix en la poesía massisiana (Bachelard, Fragmentos de una poética del fuego 69-114). No obstante, el poeta no entrega la imagen básica de doble impronta del ave que se inflama en su propio ardor y renace de sus cenizas. En su lugar, ofrece una versión particular, por ejemplo, en el poema "El rayo trastornado" pues se presenta cual rayo desprendido de una tormenta para caer en un vórtice en el mar que, sin embargo, no se extingue; por un instante brilla y luego cae en el abismo. Así, el yo lírico declama: "Este mar, tan duro, que mueve su escoba negra,/ mar de peste en la noche. ¡Qué látigo/ en las pobres espaldas! Qué rayo trastornado/ en la lengua inútil, en el trapo de la muerte sin espaldar.../... Tú giras, giras sin cesar en el molino,/ en el gas verde, ave en demolición en la tormenta,/ huracanado, febril, alzando tu pierna de gallo.../... Pero estás vivo, como un papiro salvado de las aguas,/ encendiéndote entre derrotas, moviéndote en pálidas fulguraciones.../... retardando la caída al hoyo negro,/ al espanto negro.../... pero inevitable en su nocturno sentido" (Massís, Antología, "El rayo trastornado" 100). Sin duda, en estos versos se construye una imagen dinámica de la rapidez ( $\mathrm{An}$ tología 73 y ss): "el rayo trastornado" es un trazo de fuego que está en lugar de la imagen del pájaro de fuego; un sentido posible del "rayo" es mostrar al hombre en un instante del universo y solamente en ese momento fugaz, porque su destino es, según el poeta, "inevitable en su nocturno sentido". El Fénix massisiano no renace; triunfa la muerte.

Presencia de Heráclito. La vida y muerte son convivencias simultáneas que subyacen en los poemarios massisianos. El poeta establece que la vida conlleva una carga trágica y sombría que se encamina inexorablemente hacia la muerte. En este sentido, Massís se transforma en un poeta heracliteano, pero su panta rei, esto es, 'todas las cosas fluyen', está determinado por una visión angustiosa, descarnada y cruel. Es a través de este fluir donde la 
apariencia del ser se debate en esa doble mirada del vivir y morir; pero este morir es ad aeternum. He aquí algunos escenarios heracliteanos:

El hablante lírico adopta la voz del comerciante para criticar al mundo actual. Según él, hay una parte de la naturaleza que perdurará, y esta es el oro, mientras que el sol, símbolo de la luz, la vida, el eterno retorno, será vencido por la muerte destructiva: “... Se agusanó el sol, viejo Heráclito. ¡Nada permanece!/ ¡Se agusanó la vida! Sólo refulge el oro/ antiguo de los mariscales. / El oro idiota./ Belcebú, aquí está mi alma. ¡Entrégame el metal pálido..." (Massís, Antología, "Elegía del oro" 78).

El hablante lírico ha percibido desde siempre que su alma -otrora celestial y cósmica- ha sido condenada a un juicio injusto de dioses petrificados: “... ¡Oh, alma mía! ¡Cuánta justificación para vivir!/ Un día te cubrirán las aguas, descenderás hasta los/ continentes vivos en otro tiempo;/ entonces, alma mía, pájaro ensoberbecido por la tristeza/, alguien más negro que tú, alguien cuya cabeza asoma entre/ los fosos,/ anegará tus alas antaño azules, tu respiración entrecortada,/ arrastrándote, cortando tu cuello,/ abandonándote entre los dioses del mar, injustos y/ eternamente estables" (Massís, Antología, "Poema 26", 58).

No obstante, el poeta recupera la imagen poética del río heracliteano con características propias. Es el río de la muerte que espera a los moribundos y los recibe con sonidos misteriosos, vetustez y silencio. Así declama el yo lírico: "Este río que arrastra muertos y una lágrima negra,/ y huevos de alquitrán y flor de espliego,/ cae sobre el lecho en la última tarde de la vida,/ entre atambores y guedejas de ayer, y el metal pálido/ de harapos desvanecidos, de una muerta cierta en la lengua..." (Massís, Antología "Última tarde" 97). Se trata de un río mortal, conductor de los muertos hacia un universo vacío y exorcizado.

Las aguas del devenir massisiano tienen tonalidades oscuras, tenebrosas e, incluso, devoradoras; se trata de un fluir acuoso, sombrío, terráqueo y cósmico. El hablante lírico que las remonta busca a la divinidad infructuosamente. De este modo, se lee: "Entristecido, como Odiseo,/ como un enano muerto en el fondo de una copa,/ remonto este estadio negro,/ buscando a Dios, enflaquecido de andar por la tierra./ Asesiné la razón, navegué en oscuras devoradoras aguas, / y un vasallaje aterrador iluminó el perro sombrío de la memoria./...Después lloré a los muertos. Bajé al limo/ de las inundaciones. Sobre mi corazón cayeron/ los petreles, y fui saludado con golpes en los ojos..." (Massís, Antología, "El aparecido" 117). Sin duda, la mención de esta agua invadida de oscuridad responde a lo que Bachelard denomina la 
"estinfalización" 33 , y denota la imaginación melancólica del poeta, cuyo estro está deformado por la materia tenebrosa y desolada de su percepción del mundo.

El mito de Caronte ${ }^{34}$. Relacionado con el tema anterior, los discursos poéticos massisianos ofrecen, en su conjunto, diferentes viajes en imaginarios navíos en su tránsito hacia territorios insondables y misteriosos. La despedida al borde del mar, dice Bachelard, es el sentimiento “... desgarrador y el más literario de los adioses...Despierta sin duda en nosotros los ecos más dolorosos..." (Bachelard, El agua y los sueños 117-118). En este ámbito de la despedida al borde del mar, el poeta introduce una ruptura significativa en relación con dos mitos: primero, con el mito de la barca de Re, revelado en el Libro de los muertos ${ }^{35}$, cuya barca transita por el submundo para renacer con el nuevo sol a un nuevo día, y segundo, con el de la barca de Caronte, cargada de muertos y navegando por el Aqueronte. Un ejemplo de este último mito se encuentra en la sustitución de la barca por un galeón -un navío más acorde con la impronta latinoamericana del autor-, que tampoco navega en el mar ni en aguas subterráneas, sino que se arrastra. Así, el hablante lírico percibe que: “... Un lejano galeón viene sonando/ y en el subsuelo arrastra su cruel ferretería,/clavando siempre, clavando en mi corazón,/ como a un sarcófago que se abriera en medio de la tempestad de la noche..." (Massís, Antología, "Gehenna" 15). Del mismo modo, el hablante se presenta en otros tipos de barcas: en una emprende su viaje en su sarcófago hacia la inmensidad cósmica; en otra la divinidad queda detenida con su galeón de muertos: “... Tú te sonríes, señor de los ejércitos./ Yo empuño los remos de mi sarcófago hacia las banderas azules./ Tu galeón está sujeto por una flota de cadáveres" (Massís, Antología, "La gran noche" 24).

A veces, el hablante lírico convierte la barca en una sombra que se arrastra: “¿De dónde, desconocida sombra, detrás de qué sepultura/ tu substancia inmóvil se arrastra,/ descendiendo de los pórticos, cayendo/ con tu tranquilo paso de res?/ Infante de doble faz, fantasma de las paredes, / te ocultas en las columnas de los bulevares, / arrastrando tu ferretería, haciendo sonar tu pífano seco..." (Massís, Antología, "Poema 23", 55).

33 Véase Gaston Bachelard. El agua y los sueños.

34 Véase Gaston Bachelard. Capítulo III. "El complejo de Caronte. El complejo de Ofelia”. En El agua y los sueños, pp. 111- 143.

35 Véase Libro de los muertos. Edición citada, capítulos 97 - 102, pp. 158 - 175. 
La barca metaforizada se convierte en un ángel subterráneo con alas de metal que conduce al hablante-difunto: "Ángel descabellado que me arrastras,/ apretando mi sien contra los castaños, torciéndome/ la quijada, ¿qué dios/ financia tu obcecación? ¿hasta qué rincón me persigues?.../...Mas la ferretería de tus alas golpea en mi litera de piedra,/ su pecho de jabalí gotea sobre el mío, lentamente se oxida..." (Massís, Antología "Poema 27", 59).

También para el hablante lírico un ataúd es una barca que remonta el vuelo a la eternidad; después navega sin tiempo. Esta barca-ataúd, por ende, difiere de la barca del infortunio de Bachelard que "... se dirige siempre a los infiernos..." (Bachelard, El agua y los sueños 124): "En mi caja negra,/ cubierta de alas de estaño y mariposas,/ como un juez antiguo atravieso la eternidad,/ navegando entre tortugas y grandes árboles, recordando/ mi juventud, los años perdidos, respirando/ la cecina del aire y el pájaro quebrado del alma..." (Massís, Antología, "Día de visita" 66). Puede ser también un barco de piedra que transporta el cadáver: “... Pero aunque fuese la mitad de su espectro, una flor,/ una mosca de su esqueleto, todo basta/ para el velamen de este barco de piedra hacia lo desconocido..." (Massís, Antología, "Océano abierto" 89).

El mito de Ofelia ${ }^{36}$. La inserción de este mito en algunos poemas obedece a que Massís descubre en el suicidio de una mujer una dimensión trágica de la muerte. Precisamente, el hablante lírico convoca esta imagen ofelina, la reconstruye en diversas situaciones y, en general, la instala rodeada de agua porque es su elemento de la muerte (Bachelard, El agua y los sueños 128): “... un ángel cargado de azucenas golpea la sien anegada, / muerta en la víspera de la ensoñación, caída/ en la corriente del Golfo, y, en verdad, ahora crece/ sobre la frente de Ofelia un papiro de sangre" (Massís, Antología "Poema 22" 54). A veces, el hablante lírico poeta requiere de esta imagen de Ofelia para asimilarla a la muerte de otra mujer en el río, causada tal vez por la Dictadura. Allí, con tono de dolor, promete: “...Sólo silencio y una golondrina/ muerta cuando pasó la turba/ de Nerón,/ y tu cadáver, como el de Ofelia, se fue por el angosto río./ Por ese mismo río volveremos/ a rescatarte, / compañera." (Massís, Antología "V", 133). Igualmente, el yo lírico crea una sinécdoque poética ofelina, de carácter legendario, para conjurarla en una suerte de ninfa

36 Este personaje aparece en el drama de William Skakespeare Hamlet. Acto IV, escena VII. 
lavándose sus cabellos (Bachelard, El agua y los sueños 130 y ss.): “. . y hablo con los pájaros/ como el espectro de Gilgamesh entre las ruinas,/ evocando a la que lava/ su guedejas/ a orillas del mar..." (Massís, Antología, "I", 129). En otra sinécdoque, al hablante lírico solo le basta mencionar tres términos -diosa, cadáver, cabellera- para aludir a Ofelia mientras implora: “... Entre lo perros muertos de la estación yace su cadáver de diosa. /Señor, sobre su invulnerable/ cabellera, entre la resolana y el cuero del pasado lluvioso,/ envía esta noche un ángel..." (Massís, Antología "Entierro" 76). Asimismo, cuando el hablante lírico se autopercibe cual sombra que atraviesa las aguas, o como esqueleto, se dirige a esa imagen ofelina, simbolizada en su cabellera larga que llega hasta el mar, en una búsqueda de la vida o la muerte: "Mi sombra atraviesa el agua,/... Mi esqueleto/ se desploma sobre el follaje.../ Niña mía, cuya cabellera llega hasta el mar,/ olvida esa mariposa de santo/ salobre, / aquella ferretería desparramándose..." (Massís, Antología, "II", 130).

Búsqueda de una trascendencia. El universo reconstruido por el poeta se caracteriza por aparecer fragmentado, silencioso, carente de renovación y regido por una divinidad remota, inalcanzable, imperturbable. Este universo es, sin duda, una suerte de abismo invertido (Bachelard, La tierra y los ensueños de la voluntad), un espacio de hostilidad o topofobia, idea contraria de topofilia (Bachelard, La poética del espacio 29); no obstante, captado como espacio feliz por la imaginación massisiana, en el cual residen imágenes apocalípticas, en que la muerte invade todo con una visión sobrecogedora. En este cosmos habitan los astros apagados, "en un firmamento inmóvil" (Massís, Antología, verso de "Poema 4", 36), en cuya “... eternidad de polvo ya nadie escucha" (Massís, Antología, verso de "La búsqueda", 67). Por consiguiente, se trata de un universo negro como reflejo de los abismos de la tierra negra de muerte y desolación.

Ante este panorama funerario y lúgubre, y a pesar de un estado de duelo permanente por el destino trágico del hombre y del cosmos, todavía es posible desentrañar la intención y el anhelo del poeta por vencer a la muerte y buscar desesperanzado una posible redención y trascendencia. En esta perspectiva, hay huellas de una orientación órfica en sus poemarios. El poeta, descendido en su infierno creado, eleva un alarido sin destino, incierto y aterrador a un cosmos donde habita una divinidad lejana e indiferente. Así, el grito del hablante lírico desolado exclama: “... tantas veces bebiendo la amarga saliva de los lobos,/ tantas veces haciendo un pedernal con mis rodillas/ para alumbrar mi alma./ Tantas veces vociferando como un gallo a la eternidad./ ¡Tantas veces sorda!” (Massís, Antología "Los cerrojos” 21). En 
otro contexto, el hablante lírico se siente condenado por ese Dios-Padre que le impide crear o tal vez soñar, y entonces exclama: “...Oh, Padre, levanta entre los sarcófagos tu escudo./...Sostengo, sin embargo, el taladro de tus ojos,/ tu farol de yeso, tus dientes de sílice escarlata./ Pero soy quien aúlla./ ¡SOY YO QUIEN AÚLLA Y TÚ NO ME CONOCES!” (Massís, Antología, "Elegía del condenado" 83) ${ }^{37}$. A veces, el hablante lírico desacraliza a este Dios y desde su tumba le grita: “... y yo debajo de ti, inconexo, agarrado a las muelas del alma,/ rodando en los acantilados, escurriéndome/con la cabeza abierta, el pecho abierto, la boca abierta,/ y gritándote desde abajo:/ ¡BARRABAS!" (Massís, Antología, "Sonata del padre eterno" 94) ${ }^{38}$.

En consecuencia, Massís contempla un mundo yermo, no puede salvarse en él, se sabe desconcertado y desvinculado de Dios; y, sin embargo, su lírica contiene una necesidad de trascender. Este profundo anhelo del escritor se cifra en una imagen dinámica integrada por la larva, el gusano, la lombriz y la mariposa, los cuales sugieren un indicio revelador del poeta en su búsqueda de vencer el sentido de una muerte eterna. Así, en determinados poemas el hablante lírico se revela desvinculado del poder divino; su triunfo sobre la muerte se debe al poder y la fuerza de la naturaleza y de la creación: “... En la gran noche yo te entrego mi puñado de larvas./ Sin embargo,/ ¡están para tu piedad mis pies tan fríos!/ Gusano de palo verde por mis huesos trenzados, / señora de almendro claro ¡cómo tengo la vida!..." (Massís, Antología, "La gran noche" 24); también el hablante lírico señala que solo cree en la materia capaz de superar y aniquilar la noción de Dios: “... Pienso: sólo el gusano verá el diluvio, él es eterno./ ¿Cuándo devorará a Dios?” (Massís, Antología, "Cruz baldada" 20). Pero todavía la voz lírica clama desesperada su deseo de trascender "¡Mi reino por un gusano!" (Massís, Antología, "El monstruo" $72)^{39}$. También menciona a las lombrices que le sirven para indicar no solo la descomposición de los muertos, sino que ellas anuncian su vuelta al ciclo vital: “... De noche yo fraguo una espada,/ y un sudor mineral me ciñe el esqueleto,/ inyecta su alcanfor en mi alma,/ y un hueso señalador recusa la tristeza/ y una filial bandada de lombrices/ inicia su vuelo hacia la altura". (Massís, Antología, "Roncan los espectros" 19). Y además se observa una

37 Las mayúsculas pertenecen al poema.

38 La mayúscula es del poema.

39 En rigor, es "Mi reino por un caballo", en el drama Ricardo III, de Shakespeare. En esta obra el rey había sido derrotado y clamó por un caballo para huir y salvarse de la muerte. 
búsqueda de la trascendencia con el empleo de la mariposa: "En mi caja negra,/ cubierta de alas de estaño y mariposas,/ como un juez antiguo atravieso la eternidad..." (Massís, Antología, "Día de visita" 66).

La imaginación poética del escritor Mahfud Massís es un reino autónomo, irreductible, construido a base del descubrimiento que hace del horror de la muerte, el tormento del dolor, la soledad y el desamparo celestial, la muerte de sus hermanos, padres y amigos, la deshumanización del mundo, la expulsión de sus ancestros de la tierra árabe y su condición de desterrado. Todo este material violentó su realidad, transformándola en materia poética, en la que la muerte es presentada como disolución del cuerpo, desintegración del ser y una búsqueda casi siempre infructuosa de la trascendencia.

\section{BIBLIOGRAFÍA}

FUNDAMENTAL

Massís, Mahfud. Litoral celeste. Poesía. Santiago de Chile: Yunque, 1940.

Las bestias del duelo. Poesía. Santiago de Chile: Multitud, 1948.

Elegía bajo la tierra. Santiago de Chile: Ediciones "Polémicas", 1955. s/pp. In-

troducción "Palabras en el muro". Antología. Poemas 1942-1988. Caracas: Dialit, 1990.

Papeles quemados. Editor Naín Nómez. Santiago de Chile: LOM, 2001.

\section{Bibliografía CRÍTICA}

Bachelard, Gastón. El psicoanálisis del fuego. Buenos Aires: Schapire, 1953.

El aire y los sueños. México: F.C.E., 1958.

La poética del espacio. México: F.C.E., 1965.

Lautréamont. México: F.C.E., 1985.

La intuición del instante. México: F.C.E., 1987.

Fragmentos de una poética del fuego. Buenos Aires: Paidós, 1992.

El agua y los sueños. México: F.C.E., 1996.

La tierra y los sueños de la voluntad. México: F.C.E., 1996.

La poética de la ensoñación. México: F.C.E., 1998.

Campaña, Antonio. "Panorama de la poesía chilena del siglo XX", acápite "Poetas de la generación de 1938”. Pasión sin pausa: poetas, poesía, antipoesía. Santiago de Chile: Ediciones del Instituto de Estudios Poéticos, 2000.

Campbell, Joseph. El héroe de las mil caras. México: F.C.E., 1959.

Las máscaras de Dios. Madrid: Alianza, 1991. 
Mitos, sueños y religión. Barcelona: Kairós, 1997.

Cano, José Luis. La poesía de la generación del 27. Madrid: Guadarrama, 1970.

Cernuda, Luis. “Generación de 1925”. Estudios sobre poesía española contemporánea. Madrid: Guadarrama, 1957. 181-196.

Compte de Lautreamont. Cantos de Maldoror. México: Coyoacan, 1994.

Correa, Carlos R. “Gustavo Ossorio”. Poetas chilenos del siglo XX. Santiago Chile: Zig- Zag, 1972, Tomo I, 287-289 y "Enrique Gómez Correa”, Tomo II, 321.

Diel, Paul. Psicoanálisis de la divinidad. México: F.C.E., 1959.

El simbolismo en la mitología griega. Barcelona: Labor, 1976.

Los símbolos de la Biblia. México: F.C.E., 1989.

Díez, Francisco. Panorama crítico de la generación del 27. Madrid: Castalia, 1987.

Drioton, Étienne y Jacques Vandier. Historia de Egipto. Buenos Aires: EUDEBA, 1964.

Eliade, Mircea. La muerte, la vida después de la muerte y la escatología. Buenos Aires: Megápolis, 1978.

Lo sagrado y lo profano. Barcelona: Guadarrama, 1981.

Imágenes y símbolos. Madrid: Taurus, 1989.

El mito del eterno retorno. Madrid: Alianza, 1989.

El vuelo mágico. Barcelona: Siruela, 1995.

Ferrero, Mario. "La prosa chilena de medio siglo". Atenea 386 (1959): 137-157.

Fernández, Teodosio. "Una generación de poetas chilenos". 10 años de poesía chilena (1910/1924). Madrid: Orígenes, 1991.

Frazer, J. F. La rama dorada. México: F.C.E., 1969.

Gavilán, Ismael. “Caracterización de la Generación del 38”. Cyber Humanitatis 37 (verano 2006).

Goić, Čedomil. “Generación de 1942”. Historia de la novela hispanoamericana. Chile: Universitarias de Valparaíso, 1972. 117-244.

Gullón, Ricardo. "La generación poética de 1925”. La invención del 98 y otros ensayos. Madrid: Gredos, 1969. 126-161.

Herodoto Los nueve libros de la historia. Libro Segundo "Euterpe", capítulos CLXXIICLXXXII. Buenos Aires: Librería Perlado, 1945.

Jung, Carl Gustav. Símbolos de transformación. Buenos Aires: Paidós, 1952.

Psicología y religión. Buenos Aires: Paidós, 1955.

El yo y el inconsciente. Barcelona: Miracle, 1955.

Recuerdos, sueños, pensamientos. Barcelona: Seix Barral, 1964.

El hombre y sus símbolos. Barcelona: Caralt, 1984.

Jaspers, Karl. Esencia y formas de lo trágico. Buenos Aires: Sur, 1960.

Kramer, Noah. La historia empieza en Sumer. Barcelona: Aymá, 1978.

La Biblia Madrid: Paulinas, 1991. 
Libro de los muertos. Ed. Federico Lara Peinado, Madrid: Tecnos, 1989.

Martínez, Pedro. "Literatura del Mahyar". Introducción a la literatura árabe moderna. Madrid: Almenara, 1974.

May, Hilda R. La poesía de Gonzalo Rojas. Madrid: Hiperión, 1991.

Meyer-Minnemann, Klaus y Sergio Vergara Alarcón. "La revista Mandrágora: vanguardismo y contexto chileno en 1938”. Acta Literaria 15 (1990): 53-54.

Montes, Hugo y Julio Orlandi. “Generación de 1942, Realismo populista. Neocriollismo”. Historia y antología de la literatura chilena. Santiago de Chile: Zig-Zag, 1969. 143-161.

Muela G., Joaquín. El lenguaje poético de la generación Guillén-Lorca. Madrid: Ínsula, 1954.

Nómez, Naín. Ed. “Introducción”. Antología crítica de la poesía chilena. Tomo II. Santiago: LOM, 2000.

"La poesía de los cincuenta: aproximaciones a una modernidad en disolución". Taller de Letras 34 (2004): 85-96.

Poema de Gilgamesh. Ed. Federico Lara Peinado. Madrid: Nacional, 1983.

Rozas, Juan M. La generación del 27 desde dentro (Textos y documentos). Madrid: Alcalá, 1974.

Santana, Francisco. "La Generación de 1938". Evolución de la poesía chilena. Santiago de Chile: Nascimento, 1976. 202-254.

Silva, Jorge. Gilgamesh o la angustia por la muerte (poema babilonio). Traducción directa del acadio, introducción y notas de Jorge Silva Castillo. México: El Colegio de México, 1995.

Teitelboim, Volodia. "La generación del 38 en busca de la realidad chilena". Atenea 380-381 (1958): 106-131.

Torre, Guillermo de. Literaturas europeas de vanguardia. Madrid: Guadarrama, 1971.

Undurraga, Antonio de. Atlas de la poesía chilena. 1900-1957. Santiago de Chile: Nascimento, 1958.

\section{DicCIONARIOS}

Corriente Federico. Diccionario árabe- español. Barcelona: Herder, 1991.

Chevalier Jean. Diccionario de los símbolos. Barcelona: Herder, 1988.

Diccionario de la Real Academia Española. Madrid: Espasa Calpe, 2001.

Diccionario Enciclopédico de las Letras de América Latina. Caracas-Venezuela: Monte Ávila Editores, 1995.

Morales, Félix. Nuevo diccionario ejemplificado de chilenismos. Valparaíso: Puntángeles de la Universidad de Playa Ancha, 2006.

\section{EN INTERNET}

Mandrágora - Retablo de literatura chilena: http:// www.mandragora.uchile.cl.

http://www.poesiaarabe.com/poetas_palestinos.htm 